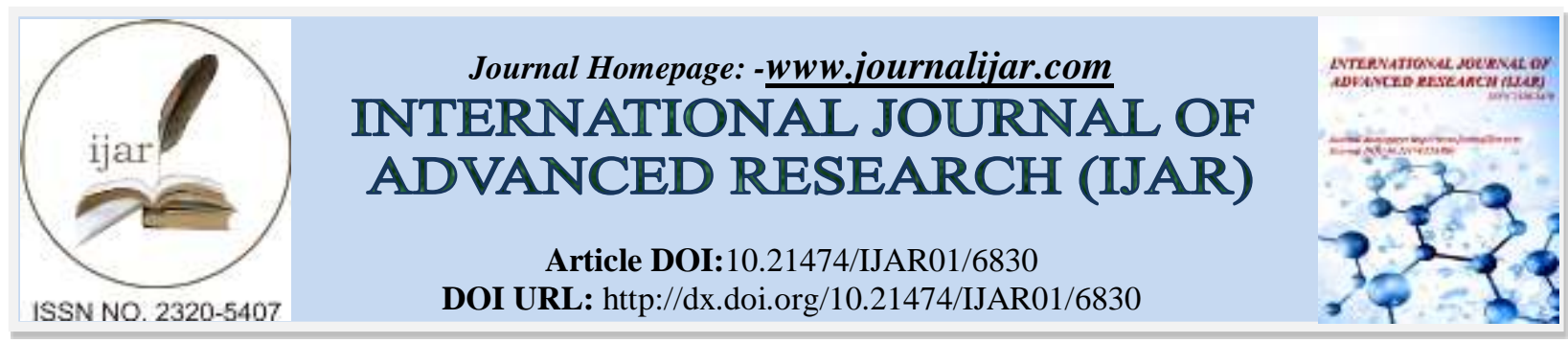

RESEARCH ARTICLE

\title{
MONITORING OF PHENOLIC COMPOUNDS AND SURFACTANTS IN WASTE WATER MIXING WITH NARMADA RIVER AT JABALPUR, (INDIA).
}

\author{
Anjana Sharma ${ }^{1}$, Preeti Bala Pal ${ }^{1}$, Meenal Budholia Rehman² and Juhi Sharma ${ }^{3}$. \\ 1. Bacteriology Laboratory, Department of P. G. Studies and Research in Biological Science, Rani Durgavati \\ University, Jabalpur, Madhya Pradesh, India. \\ 2. Department of Botany, Mata Gujri Women's college, Jabalpur (M.P), India. \\ 3. Assistant Professor, St. Aloysius College, Jabalpur (M.P), India.
}

\section{Manuscript Info}

Manuscript History

Received: 03 February 2018

Final Accepted: 05 March 2018

Published: April 2018

Keywords:-

River water, Phenol, Surfactant,

Monthly analysis.

\section{Abstract}

The Khandari Nala mixing with Narmada River inflict an assortment of organic pollutant in river Narmada has enormous ritual consequence among pilgrims and tourists at Jabalpur, Madhya Pradesh, India. The River bank is being polluted due to mass bathing, washing, disposal of sewage, industrial waste and these human activities are abating its water quality. To conclude the collision of these activities, Narmada water quality at diverse sites has been analyzed for organic pollutants phenolic compounds and surfactants, which have rarely been assessed and reported so far. The grades of scrutiny show that phenolic compounds are present in water samples of selected sites during monthly monitoring from September 2015 to August 2016. The site Khandari Nala mix with back wash have been detected with surfactant concentrations more than permissible limit $(1.00 \mathrm{mg} / \mathrm{l})$. Also at most of the sites, phenol concentration crossed the desirable limit of BIS during the period of analysis. This distribution of surfactants and phenol in water has potential risk for skin diseases and cancer and requires regular monitoring with appropriate measures. This study is imperative because more than treatment measure continuous assessment is important to design appropriate remediation strategy.

Copy Right, IJAR, 2018,. All rights reserved.

\section{Introduction:-}

Phenol derivatives are mainly used in several industrial processes to manufacture chemicals such as pesticides, explosives, drugs and dyes are one of the most important contaminant present in environment. The apart from these, in agriculture as herbicides, insecticides and fungicides are also the important application of phenolic compound (Timur et al., 2003; Fang et al., 2006).

Phenolic compounds also formed naturally, e.g., during the decomposition of leaves or wood they are also anthropogenic in nature. As a result of these applications, they are found in soils and sediments and this often leads to wastewater and ground water contamination. They are more harmful due to high toxicity and long persistence in the environment (Seth et al., 2013). Phenols and substituted phenols are important pollutants in water because of 
their wide use in many industrial processes, such as the manufacture of plastics, dyes, drugs, antioxidants and pesticides (Gonzále et al., 2003; Li et al., 2009).

Phenolic compounds belong to the second class of pollutants (NEPBC, 1989) in environment. (Wei, 1990; James et al., 2001), and also from the catabolism of natural or chemical products (Bai, 1984; James et al., 1984). Phenol is harmful to personal health and affects the breeding of hydrobios, due to the smell and toxicity (Willen, 1977). Exposure to high concentration of phenol in water for long duration is reported to cause paralysis and severe injury to heart, liver, kidney and lungs and in some cases may cause death also 4-5. OSHA (occupational safety and health administration) has set a limit of $5 \mathrm{ppm}$ in air, for workers during 8 hour work shifts. The US Environmental Protection Agency recommends rejection of water for drinking purpose which contains more than $1 \mu \mathrm{g}$ of phenol/litre (Hanif et al., 2012; Shinde 2006).

Khandari Nala carries water from various house hold sourer it carries water from local dye house varies industry which may result in release of phenol as waste. This water carried high Amount of phenol and other contaminate to river Narmada river serve as $\mathrm{H}_{2} \mathrm{O}$ source to large no of people of Jabalpur city. In spite of a number of available reports, no regular monitoring data are available for water quality characteristics especially phenolic compounds and surfactants as per Bureau of Indian Standards (BIS, 1991) about water quality of Narmada River at various sites falling under the industrial area zones of Khandari Nala and near by city Jabalpur (Sharma et al., 2018).

Studies of river water evidenced the presence of organic micro pollutants of environmental and toxicological interest, among which the substituted phenols play an important role (Etxebarria et al., 2012; Exner and Farber, 2006). The chlorination treatments in drinking water disinfection may form chlorophenols when phenolic compounds are already present in water. Their presence gives a nasty smell and taste even at a few ppb concentrations. Being an up pilgrim spot, Narmada in offer for bathing, washing purpose which releases surfactant its water. This continuous evaluation for prance of surfactant is up. The objective of this paper was to identify the presence of phenolic compounds in the river, monthly at the closing station of its basin, where its water is designed for human consumption, with the purpose of discovering the toxicity level of the water environment.

The present study was therefore, conducted to determine the concentration of these two organic pollutants in surface water quality of river Narmada which is being used for drinking and other domestic activities.

\section{Materials and Methods:-}

Reagents and solutions:-

Phenol (99\% pure, chemical grade) and other reagent were purchased from Hi-Media, Mumbai, India. 4aminoantipyrine, $\mathrm{NH}_{4} \mathrm{OH}$, potassium ferrricyanide, were procured from Merck and Bangalore Genei, India. Sample solutions were made up with double de-ionized water. All other chemicals used were of analytical grade and purchased from standard sources.

\section{Study area and sampling sites:-}

Water samples were collected monthly from September 2015 to August 2016 from seven main sampling sites of Khandari Nala treatment plant $\left(23^{\circ} 7,54^{\prime \prime} \mathrm{N}\right.$ and $79^{\circ} 58^{\prime} 0^{\prime \prime} \mathrm{E}$.) from river Narmada $\left(72^{\circ} 82^{\prime} \mathrm{E}\right.$ to $81^{\circ} 45^{\prime} \mathrm{E}$ and between $21^{0} 20^{\prime} \mathrm{N}$ to $23^{0} 45^{\prime} \mathrm{N}$ ) to Jabalpur, Madhya Pradesh (India). GPS co-ordinates, which were collected from each site using GPS system (Garmin, 76 CSX) are given in Table 1.

For the purpose of study, river water and Khandari Nala waste water samples were collected from seven different stations: (1) Khandari Nala before treatment plant, (2) Khandari Nala mixed with ramnagra treatment plant (before treatment), (3) Fist part of treatment plant, (4) second part of treatment plant, (5) After treatment plant (treated), (6) mixed river Narmada, (7) back wash, (Fig. 1). The criteria for selecting a sampling site where it is the point from where the river leaves the city.

\section{Sample collection:-}

Preservation and transportation of wastewater samples to the laboratory and analysis were executed as per standard methods. The water samples for phenolic compounds and surfactants analysis were collected in acid leached Tarson bottles. All the samples were then transported in cooler boxed containing ice to the Bacteriology Laboratory, Department of P. G. Studies and Research in Biological Science, Rani Durgavati University, Jabalpur, Madhya 
Pradesh, India, stored at $4^{\circ} \mathrm{C}$. Samples were analyzed within $48 \mathrm{~h}$ of collection (APHA, 1998; Eaton et al. 2005; Kazi et al. 2009).

Table 1:-GPS location of sampling sites

\begin{tabular}{|c|c|c|c|c|}
\hline S.no & Site code & Name of sampling site & Latitude & Longitude \\
\hline 1. & KN1 & Khandari Nala Before Treatment Plant, & $23^{0} 7,54^{\prime \prime} \mathrm{N}$ & $79^{0} 58,0 " \mathrm{E}$ \\
\hline 2. & KN2 & $\begin{array}{l}\text { Khandari Nala Mixed With Ramnagra } \\
\text { Treatment Plant (Before Treatment), }\end{array}$ & $23^{0} 7 \cdot 54^{\prime \prime} \mathrm{N}$ & $79^{0} 58^{\prime} 0 " \mathrm{E}$ \\
\hline 3. & KN3 & Fist Part Of Treatment Plant & $23^{0} 7,54^{\prime \prime} \mathrm{N}$ & $79^{0} 58 \cdot 0 " \mathrm{E}$ \\
\hline 4. & KN4 & Second Part Of Treatment Plant & $23^{0} 7,54^{\prime \prime} \mathrm{N}$ & $79^{0} 58 \cdot 0 " \mathrm{E}$ \\
\hline 5. & KN5 & After Treatment Plant (Treated), & $23^{0} 7,54^{\prime \prime} \mathrm{N}$ & $79^{0} 58^{\prime} 0 " \mathrm{E}$ \\
\hline 6. & KN6 & Mixed With River Narmada & $21^{0} 20^{\circ} \mathrm{N}$ to $23^{0} 45^{\circ} \mathrm{N}$ & $72^{0} 82^{\prime} \mathrm{E}$ to $81^{0} 45^{\prime} \mathrm{E}$ \\
\hline 7. & RN7 & Ramnagra Treatment Plant Back Wash & & \\
\hline
\end{tabular}

\section{Estimation of phenol:-}

Phenol and its derivatives were determined according to the method of Stuart et al., (1984). To different aliquots of phenol solution $(0.1$ to $1 \mathrm{~mL}), 0.05 \mathrm{~mL}$ of $6 \mathrm{M} \mathrm{NH} \mathrm{NH}_{4} \mathrm{OH}$ added and stirred. After stirring, $0.05 \mathrm{~mL}$ of aminoantipyrine $(2 \%)$ and $0.1 \mathrm{~mL}$ of an aqueous solution of potassium ferrricyanide $(8 \%)$ were added. Incubate for 15 minutes for the development of colour, the dye was extracted with $5 \mathrm{~mL}$ of chloroform and the absorbance of the extract was measured at $457 \mathrm{~nm}$. The absorbance is proportional to the concentration of phenol. A concentration of $0.001 \mathrm{mg} / \mathrm{l}$ has been recommended as desirable limit and $0.002 \mathrm{mg} / \mathrm{l}$ as the permissible limit for phenolic compound and concentration of $0.20 \mathrm{mg} / \mathrm{l}$ as desirable limit and $1.0 \mathrm{mg} / \mathrm{l}$ as permissible limit for surfactants in drinking water as per BIS: 10500 (1991). The spectrophotometer studies were carried out with Hitachi 220 spectrophotometer $\mathrm{pH}$ measurements were made with Orion 420 A pH meter-4-Aminoantipyrene (Fluka), potassium ferricyanide (E. Merck), potassium sodium tartrate (E-Merck) and phenol (E. Merck) were used.

\section{Surfactants:-}

Detergent compounds are determined using solvent extraction-spectrophotometric with Ethyl Violet method (Motomizu, et al., 1982).

\section{Results and discussion:-}

The results of analysis of phenolic compounds and surfactants observed at different sites of Khandari Nala, during September 2015 to August 2016 (Monthly) are summarized in fig. 1 and 2. During September 2015, the analytical results of waste water samples of Khandari Nala showed that out of all the sites, only UE mixed site had the surfactant value of higher $2.22 \mathrm{mg} / \mathrm{l}$, whereas, phenolic compounds were also found at UE mixed and higher 2.56 of the site studied. However, during March 2012 (when tourists start coming to Narmada river basin) surfactants were present in appreciable quantities ranging from 0.38 to $0.64 \mathrm{mg} / \mathrm{l}$ at all the seven sites of Narmada banks around Jabalpur, whereas phenolic compounds were again assessed at all the sites.

Phenol of the Khandari Nala sample ranged from $0.63-1.94$. The minimum phenol was observed during June month and the maximum phenol was registered during October month. In Khandari Nala mixed with back wash it ranged ranged from $0.45-2.56$. The minimum phenol was observed during April month and the maximum phenol was registered during September month. At Khandari Nala treatment plant (First) sample ranged from $0.67-1.76$. The minimum phenol was observed in March and the maximum phenol was registered during October. And phenol ranged of the Khandari Nala treatment plant (Second) sample ranged from $0.56-1.16$. The minimum phenol was observed during February and the maximum phenol was registered during November. And after treatment plant of the sample ranged from 0.45- 1.01. The minimum phenol was observed February and the maximum phenol was registered during November. And phenol ranged of the Khandari Nala treatment plant sample ranged from $0.56-$ 1.16. The minimum phenol was observed during February and the maximum phenol was registered during November. And after treatment plant of the sample ranged from 0.45-1.01. The minimum phenol was observed February and the maximum phenol was registered during November. at mixed with river Narmada, the sample ranged form 0.32-0.98. The minimum phenol was observed during February and the maximum phenol was registered during June and October. And Ram anagram treatment plant sample ranged from 0.79-1.34. The minimum phenol was observed during December and the maximum phenol was registered during September. 
Surfactants of the Khandari Nala sample ranged from $0.23-1.75$. The minimum Surfactants were observed during December and the maximum Surfactants was registered during October: Khandari Nala mixed with back wash ranged from $0.34-2.22$. The minimum Surfactants were observed during January and the maximum Surfactants was registered during September. Khandari Nala treatment plant (First) ranged of the sample ranged from $0.21-$ 1.45. The minimum Surfactants were observed in January and the maximum Surfactants was registered during September. And Surfactants of the Khandari Nala treatment plant (Second) sample ranged from 0.45 - 1.05 . The minimum Surfactants were observed during March and the maximum surfactant was registered during May. And after treatment plant of the sample ranged from $0.32-0.98$. The minimum Surfactants was observed March and the maximum Surfactants was registered during May. at mixed with river Narmada, the sample ranged from 0.37 - 0.85 . The minimum Surfactants were observed during July and the maximum Surfactants was registered during October. And Ram anagram treatment plant sample ranged from 0.74 - 1.45. The minimum Surfactants was observed during June and the maximum Surfactants was registered during November.

The above monthly monitoring study, was carried out for a period of 12 months, clearly shows that Narmada River banks near Jabalpur is not at all polluted by phenolic compounds at all the five sampling sites selected for analysis. However, the effects of mass bathing and washing are clearly visible due to the presence of surfactants at all the five sites during March to November. In the month of January, the surfactants were detected in the study sites due to less anthropogenic activities as well as not a peak season for tourist activities. Figure1 clearly demonstrate the highest concentration $(3.20 \mathrm{mg} / \mathrm{l})$ of surfactants' obtained at site and minimum concentration $(0.31 \mathrm{mg} / \mathrm{ml})$. The present study also find support from reports published elsewhere (Hanif et al. 2012; Murakami and Takada 2008; Mungray and Kumar 2008), which attribute presence of surfactants' in River water due to various anthropogenic activities caused by human along the stretch of Narmada River in Jabalpur.

\section{Conclusions:-}

The water quality is expected to be deteriorated through surfactants from washing of clothes as well as mass bathing activities along the stretch of Narmada River at different sites from Jabalpur. Through the present monitoring study of phenolic compounds and surfactants in the surface water of Narmada River, it concluded that so far phenolic compounds have not entered into surface water along the course of Narmada bank. Contrary to these results, the presence of surfactants, due to bathing and washing clothes along the route of Ganga Canal, is very prominent at almost all the sites. Our study shows limit was higher than permissible limit (1.00 mg/l) of BIS for surfactants. Besides at all the sites during the entire duration of studies, the values of surfactants' concentration were found more than desirable limit at all five sites during the course of monitoring. Thus, there is a need to ban the use of soap/surfactants for bathing or washing purposes to save Narmada River water from further pollution and to use its water for meeting out drinking/domestic needs through surface abstraction. The studies also highlight the need of regular monitoring of the Narmada River water as it may pollute a large fertile agricultural and, which is irrigated through its water.

\section{Acknowledgments:-}

Authors are thankful to Head, Department of P.G. Studies and Research in Biological Science, Rani Durgavati University, Jabalpur, M.P., India, for providing Laboratory facilities and Pollution Control Board Jabalpur, (M.P.) for financial assistance. 


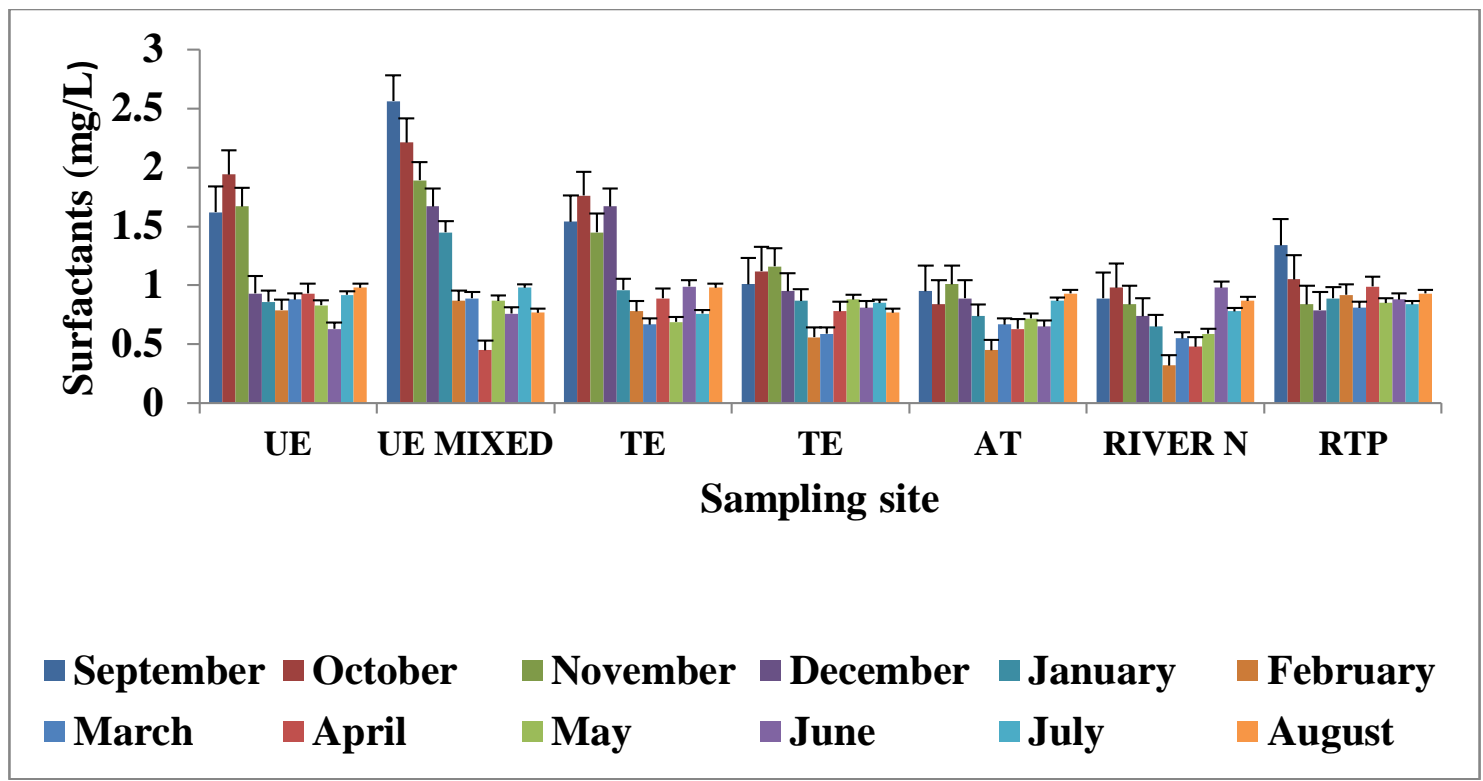

Fig.1:- Monthly variation in surfactants' concentration at all seven sites of River Narmada.

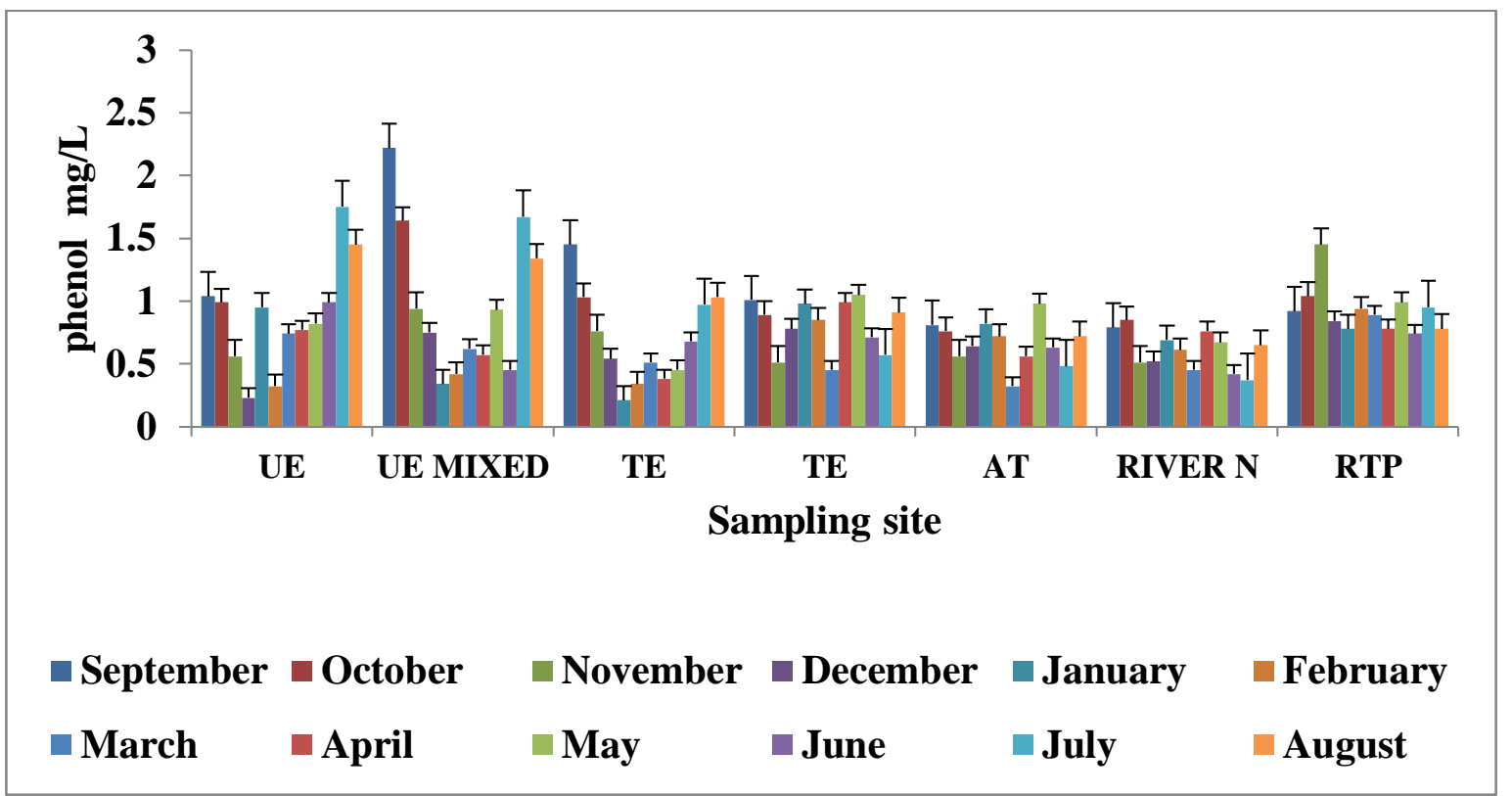

Fig. 2:- Monthly variation in phenol concentration at all seven sites of River Narmada.

\section{References:-}

1. APHA, (1998). Standard Methods for the Examination of Water and Wastewater, 20th ed. AWWA, WEF.

2. Bai, Q.B. (1984). Environmental Chemistry (Chinese). 2(3);28.

3. Bureau of Indian Standards (BIS) (1991). Specification for drinking water 1S:10500: Bureau of Indian Standards, New Delhi.

4. China Environmental Monitoring Headqarters (CEMH) (1984). Guidebook to quality guarantee for environmental monitiring of water quality .China: China. Environ. Publish .House. 243-247.

5. Eaton, A. D. Clesceri, L. S. Rice, E. W. Greenberg, A. E. (2005). Standard methods for examination of water and wastewater. Ameri. Pub. Hea. Associ. (APHA), Washington DC.

6. Etxebarria, N. Navarro, P. Priteo, A. Oilvaries, M. Usobiaga, A. Fernandex, L.A. Zuloaga, O. (2012). Extraction procedure for organic pollutants in determination in water. In: Schwarzbauer J, Robert D, Lichtfouse E (eds) Environmental chemistry sustainable world. The Nethe. Lan. 171-235. 
7. Exner, M. Farber, H. (2006). Perfluorinated surfactants in surface and drinking water. Enviro. Sci. Pollut. Res. Int. 13(5):299-307.

8. Fang, H.H.P. Liang, D.W. Zhang, T. Liu, Y.(2006). Anaerobic treatment of phenol in wastewater under thermophilic condition. Wate. Resear.40:427-434.

9. Gonzalez, M. Guzman, B. Rudyk, R. Romano, E. Molina M.A.A. (2003). Spectophotometric determination of phenolic compounds in propolis. Lat. Am. J.Pharm.22(3):243-248.

10. Hanif, N. M. Adnassssn, S. N. Latif, M. Zakaria, Abdullah, M. P. Othman, M. R. (2012). .The composition of surfactants in river water and its influence to the amount of surfactants in drinking water. World. Appl. Sci. J .17(8):970-975.

11. James, J. S. Michael, J. Kleeman, Glen, R.C. Bernd, R.T. (2001). Simoneit, Environ. Sci. Technol. 35, 17161728.

12. James, W. Moore, Ramamoorthy, S. (1984). Organic Chemicals in Natural Waters: Applied Monitoring and Impact Assessment, (Springer Verlag NewYork).

13. Kazi, T.G. Arain, M.B. Jamali, M.K. Jalbani, N. Afridi, H.I. Sarfraz, R.A. Baig J.A. Shah, A.Q. (2009). Assessment of water quality of polluted lake using multivariate statistical techniques: a case study. Ecotoxi. Envir. Saf. 72(20):301-309.

14. Li, M. Hu, C. Gao, X. Xu, Y. Qian, X. Brown, M.T. Cui, Y. (2009). Genotoxicity of organic pollutants in source of drinking water on microalgae Euglena gracilis. Ecotoxi. 18(6):669-676.

15. Mostarih, M..M..M. E.L. Madani, F. Yahya, H.S.A.E.L. Hachemi, O. Abdellaoui, S. Chafi, A. (2016). J. Mater. Environ. Sci. 7 (12): 4795-4809.

16. Motomizu, S. Fujiwara, S. Fujiwara, A. Toel, K. (1982). Solvent extraction-spectrophotometric determination of detergent compounds in solution with Ethyl Violet. Anal. Chem. 54, 392-397.

17. Mungray, A. K. Kumar, P. (2008). Occurrence of anionic surfactants in treated sewage: risk assessment to aquatic environment. J. Haza. Mater. 160(2-3):360-370.

18. Murakami, M. Takada, M. (2008). Perfluorinated surfactants (PFs) in size-fractionated street dust in Tokyo. Chemosphere. 73:1172-1177.

19. National Environmental Protection Bureau of China (NEPBC). (1989). Monitoring and analytical methods for water and wastewater (3rd edition), China: China. Environ. Publish. House. 407-412.

20. Richa, S. Singh, P. Mohan, M. Singh, R. Singh, R. Aswal G. (2013). Monitoring of phenolic compounds and surfactants in water of Ganga Canal, Haridwar (India). Appl. Wate. Sci 3:717-720.

21. Richardson, S.D. Plewa, M. J. Wagner, E. D. Schoeny, R. DeMarini, D. M. (2007). Occurrence, genotoxicity, and carcinogenicity of regulated and emerging disinfection by-products in drinking water: a review and roadmap for research. Mutat. Res; 636: 178-242.

22. Sharma, A. Pal, P. B. Rehman, M. B. (2018). Seasonal Variation of Heavy Metals in Pre and Post-Treatment Sites of Waste Water Treatment Plant at River Narmada,Jabalpur Madhya Pradesh, India . Int.J.Curr.Microbiol.App.Sci 7(3): 218-229.

23. Shinde, S.G. (2006). History of irrigation in India. National level conference on water management scenario 2025 problems issues and challenges. Department of History, VPM's Joshi-Bedekar College, Thane, pp 4-11.

24. Timur, s. Pazarlioglu, N. Pilloton, R. Telefoncu, A. (2003). Detection of phenolic compounds by thick film sensors based on pseudomonas putida. Talan. 61: 87-93.

25. USEPA. The history of drinking water treatment. United State Environmental Protection Agency; (2000). [http://www.epa.gov/ogwdw/consumer/pdf/hist.pdf. [Accessed February 15, 2013].

26. Wei, F.S. (1990). Guide to mornitoring and analytical methods for water and wastewater.China: Chin. Environme. Publish. House. 241-253. 